\title{
演題番号 2
}

\section{簡単なプログラム電卓によるアストラップ 法の計算值とグラフ值との比較}

\author{
金沢医科大学病院中央手術部 \\ 知久田博 \\ 金沢医科大学麻酔科 \\ 森秀麿
}

最近は，患者管理上血液の酸塩基平衡を測定す るのは，常識的になって来た，手術室においても 洔々刻々之変化する患者の状態を，把握するため に頻回に测定することが多くなっている，血液ガ ス分析装置でも新しいものは，計算装置が組み込 まれていて，一連のパラメーターがデジタル表示 で，あるいはプリントアウトされて出てくるが， 何分にも高価である．そこで我々は手元にある簡 単な商用プログラム電卓を用いて計算し，グラフ によって得た值との比較検討を行なったので報告 する.

\section{方 法}

Siggaard-Andersen ノモグラムによって求める方 法は，2 種類の標準炭酸ガス (high gas, low gas) の $\mathrm{P}_{\mathrm{CO}_{2}}$ と，との橴準炭酸ガスと $37^{\circ} \mathrm{C}$ で平衡さ せたときの血液サンプルの $\mathrm{pH}$ ，すなわち $\mathrm{pHL}$ お よび $\mathrm{pHH}$ とによってできる座標上の 2 点 $\mathrm{A}, \mathrm{B}$ を求めて直線を引き (Buffer line), Actual $\mathrm{pH}$ に 対応する Buffer line 上の交点 $\mathrm{C} の \mathrm{P}_{\mathrm{CO}_{2}}$ スケー ルを求めれば Actual $\mathrm{P}_{\mathrm{CO}_{2}}$ が得られる. Buffer line と Base Excess (BE) カーブ, Buffer Base (BB) カーブおよび Stand-Bicarbonate (SB) スケ ールを読めば，それぞれの価が求められる. 交点 Cを通る傾き $-45^{\circ} \mathrm{C}$ の直線と $\mathrm{SB}$ スケールとの 交点を読めば Actual Bicarbonate (AB) が求めら れる. SB スケールと Buffer line の交点から垂 線を引き $\mathrm{pH}$ スケール位置を読めば Standard $\mathrm{pH}$

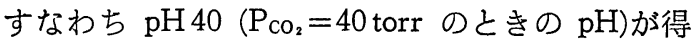

られる。

これらを計算式におきかえるには，

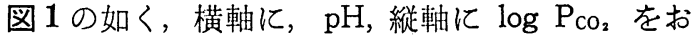
けば比例式により, Actual $\mathrm{P}_{\mathrm{CO}_{2}}$ が求められる.

同様にての式より $\mathrm{P}_{\mathrm{CO}_{2}}=40$ のときの $\mathrm{pH}$ すなわ ち $\mathrm{pH} 40$ (Standard $\mathrm{pH}$ ) が求められる.

Henderson-Hasselbach の式から

Actual Bicarbonate

$$
\mathrm{AB}=0.0306 \times \mathrm{AP}_{\mathrm{CO}_{2}} \times 10^{(\mathrm{ApH}-6.1)}
$$

及び

Standard Bicarbonate

$$
\mathrm{SB}=0.0306 \times \mathrm{P}_{\mathrm{CO}_{2}} \times 10^{(\mathrm{pH} 40-6.1)}
$$

が求められる.

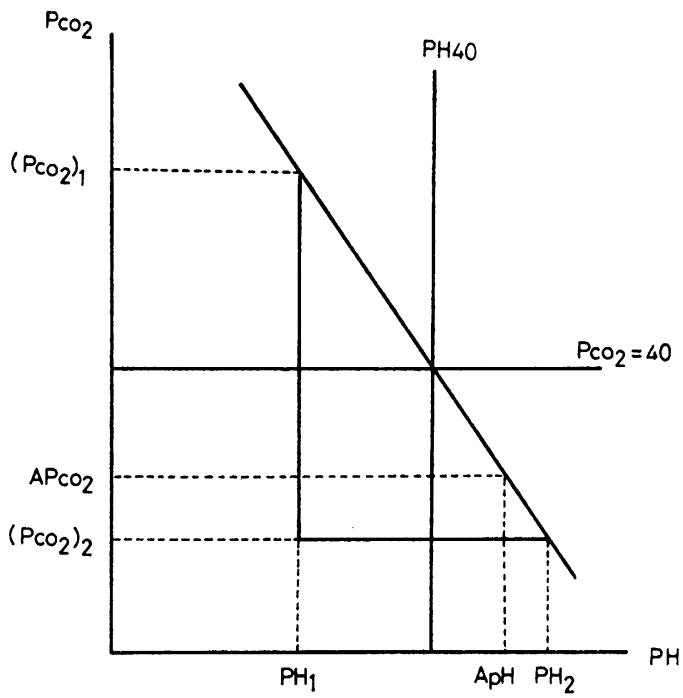

図 1 


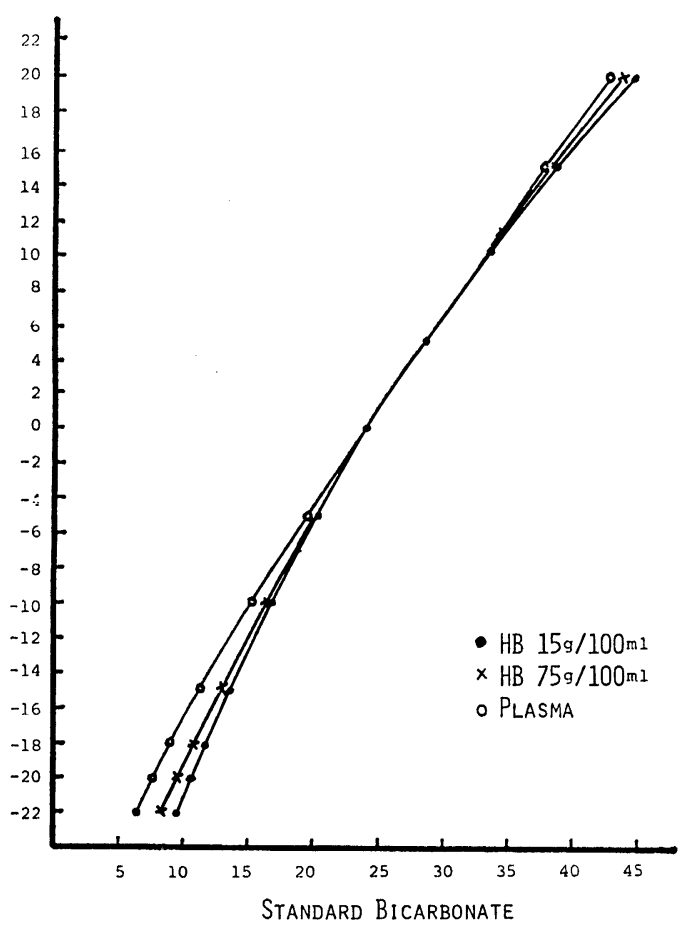

$\mathrm{BE}=-38,402+1,8970(\mathrm{SB})-0,013324(\mathrm{SB})^{2}$

$B B=B E+41,7+0,42 * H B$

図 2

$\mathrm{BE}$ は図 2 の如く，理論計算からは出すととが出 来なくて, Siggaard-Andesson ノモグラムより求 めた， SB-BEグラフより曲線がえがかれるが， こ こで $\mathrm{Hb}$ 濃度を無視すれば 1 本のカーブで好理で きる. $\mathrm{Hb}$ 濃度の差による誤差は，ての図より $\mathrm{SB}$ 15 から 40 の範囲でわずか $\pm 2.0 \mathrm{mEq} / l$ である.

従ってての図の下方に示したような 2 次式が得ら れる. BB は図 2 の下方に示した如く, $\mathrm{Hb}$ より 計算するために $\mathrm{Ht}$ 值の $1 / 3$ を使用した.

プログラム電卓としてシャープ Compet $364 \mathrm{P}$ 及び指数計算のみに YHP モデル 45 を使用した. 結 果

Actual $\mathrm{P}_{\mathrm{CO}_{2}}, \mathrm{pH}_{40}, \mathrm{AB}, \mathrm{BE}, \mathrm{BB}$ について夫々検 討した.

図 3 は $\mathrm{P}_{\mathrm{CO}_{2}}$ を示した. 横軸の $\mathrm{G}$ はグラフ值. 縦軸の $\mathrm{P}$ はプログラム計算值の意味である. $\mathrm{AP}_{\mathrm{CO}_{2}}$ は $\mathrm{r}=0.999$ であった.

図 4 $\mathrm{pH}_{40}$, 図 5 にAB, 図 6 KB, 図 $7 飞 \mathrm{BE}$ 図 8 に BB を示した。

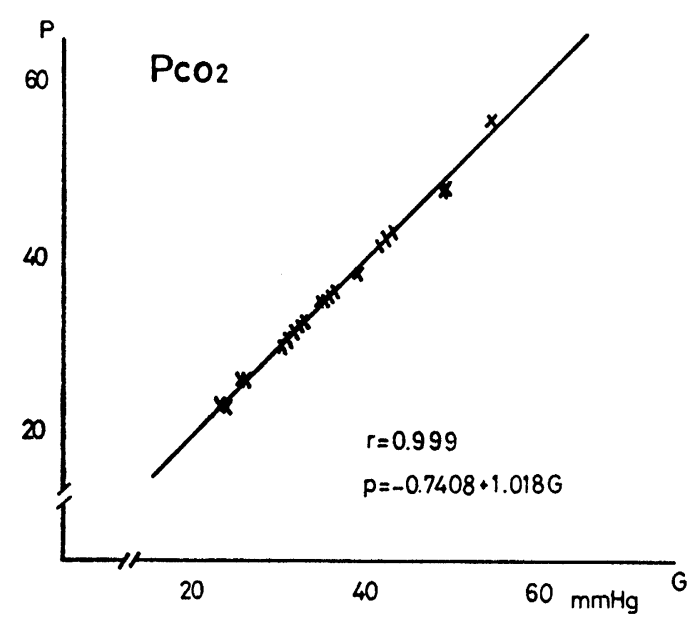

図 3

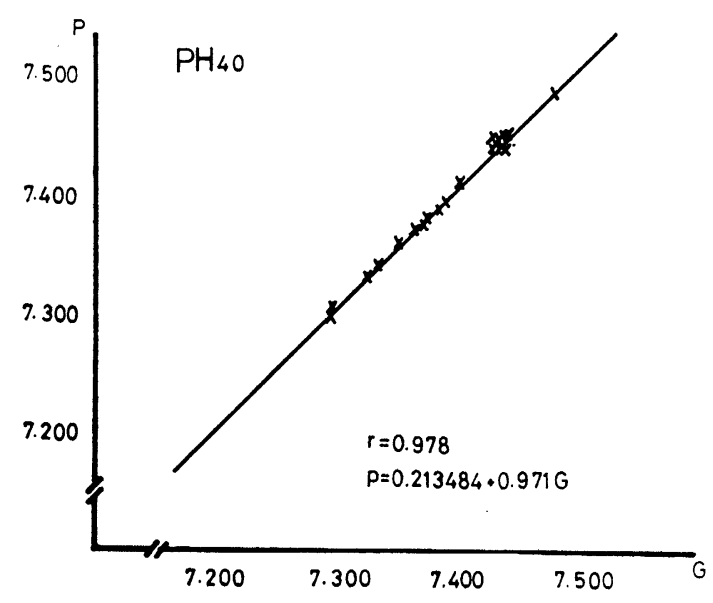

图 4

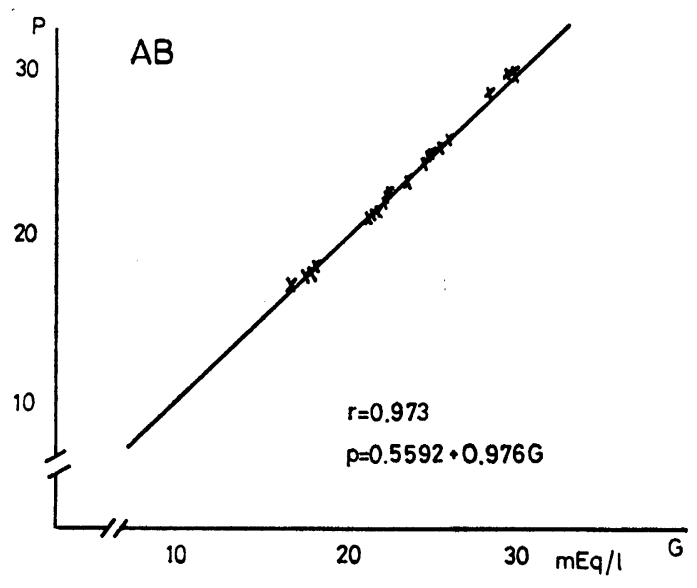

図 5 


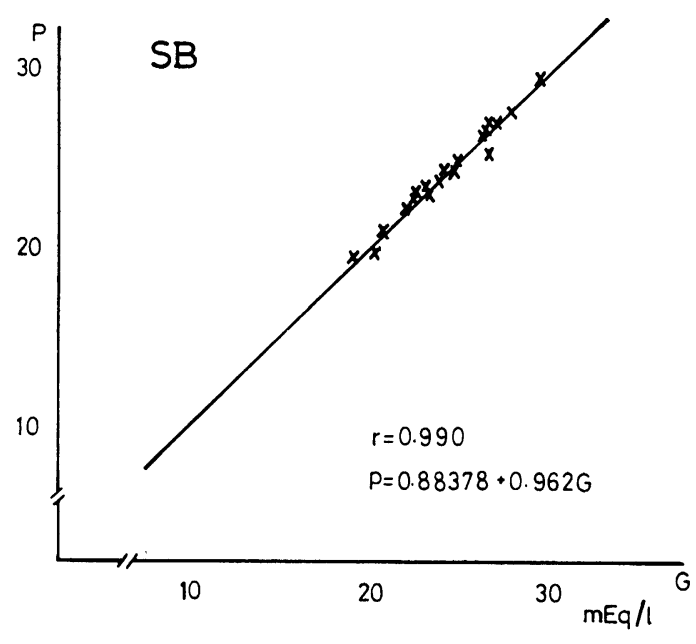

図 6

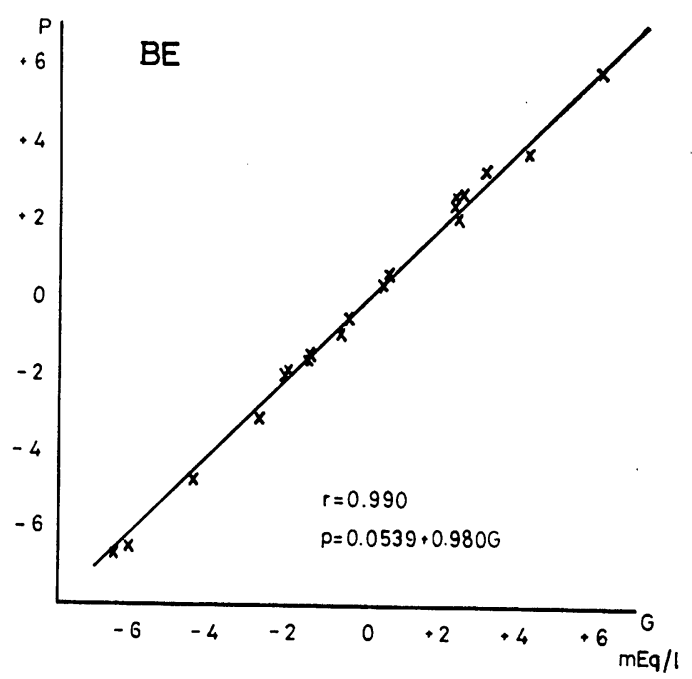

図 7

\section{考擦及び結語}

同じデーターを使用する場合，グラフによる読 みとりは，個人差の関与する因子が大であり，し かも煩雑である.

一方計算による方は $\mathrm{BE}, \mathrm{BB}$ 以外は全く同じ データーを理論式より求めるあのであるので，詔 差は 0である. 従ってむしろX軸の方に計算式を とるべきであるが，グラフ值を主においたために グラフ值をX軸にとった．乙の外に大気圧む 1 日 の間にあずいぶんと変化するものであり，それの 計算の煩雑をむ考慮に入れると，もはやグラフ值

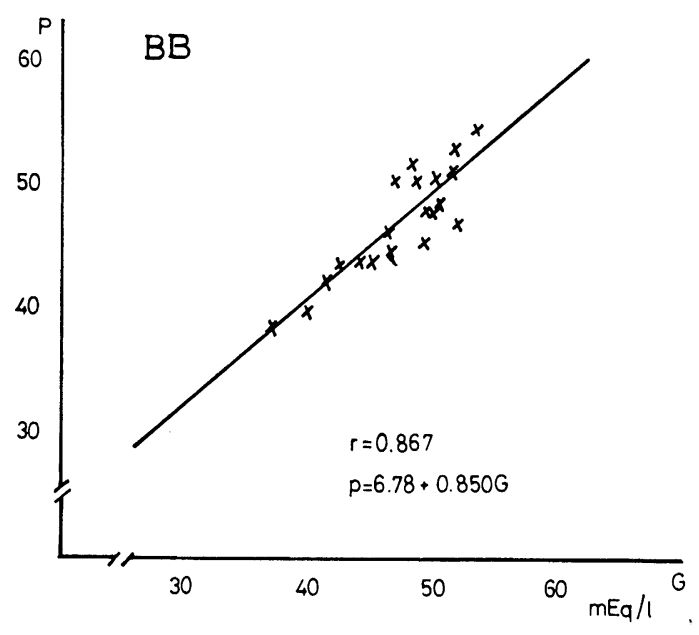

図 8

の比ではない，ただ残念なととには，これらのて とは計算器の能力によるわけであり，今回使用し たようなわずかな 144 ステップのプログラムしか 組めない，しかも関数機能をそなえていない，プ ログラム電卓では少々無理であるが不可能ではな い. 計算式を組み込んだ高価な血液ガス分析装置 よりも，せめて対数関数之指数関数の計算が可能 な，範用プログラム電卓を使用した方が，計算器 屯種々の目的に使用できて有効である. 将来病院 3 階にコンピューターが入り，せめて端末装置さ えつけば，必ずしあ real time でなくても充分で あり, on line で簡単に処理できるの，多忙な技 師を救うためにも，より簡単で正確な結果が期待 できるので，てのような方法をとるととは時代の 流れと考えている.

\section{質 問}

兵庫医大

$$
\text { 三木 仁 美 }
$$

プログラム電卓に要する時間はどの位いか？

回 答

\section{金沢医科大学病院}

知久田博

我々が使用したプログラム電卓は指数計算がそ なえてないので 1 度取り出し，YHP モデル 45 を 使用し計算し，またプログラム電卓に入れるた め, 時間が少しかかったが，指数，関数計算の可 能なプログラム電卓ならばすぐ求められる. 